\title{
The Dr. Bovary Syndrome (DBS)
}

\author{
David Welling • Norman Rich
}

Published online: 27 October 2011

(C) Société Internationale de Chirurgie 2011

\section{Introduction}

Gustave Flaubert wrote a controversial, sensational novel, Madame Bovary. It was published in 1856 in serial form and created such a sensation that Flaubert was publicly attacked and put on trial in January 1857. After he was acquitted in February 1857, the book eventually was recognized to be a masterpiece of writing, perhaps one of the finest novels ever written. Flaubert became famous and was accepted as a gifted novelist, one who struggled over finding "le mot juste," with a great ability to describe the human condition and its foibles. His novel was scandalous in its day because it dealt with the adulterous relationships of the wife of a small-town surgeon, Dr. Bovary. Buried in its pages, as a minor part of the story, is the account of some of the challenges faced by Dr. Bovary [1].

This report is about the work of Dr. Bovary and illustrates some of our weaknesses and vulnerabilities as health care providers even today. Although, fiction and set in the France of the 1800s, many of Flaubert's descriptions ring true today. Perhaps we can learn something from this story, which should, not surprisingly, remind us that human-kind has not changed much over the years. We still are easily misled, and we fall into many traps along the way.

This article presents the thoughts and the opinions of the authors and does not necessarily represent the doctrine or thinking of the Department of Defense of the United States or that of the Uniformed Services University of the Health Sciences.

D. Welling · N. Rich $(\varangle)$

Norman M. Rich Department of Surgery, Uniformed Services

University of the Health Sciences, 4301 Jones Bridge Road,

Bethesda, Maryland 20814, USA

e-mail: dwelling@usuhs.mil

\section{Background of Dr. Bovary}

The novel begins as a 15-year-old Charles Bovary was introduced to his classmates at a new school. He was older, taller, and quickly became the object of jokes and ridicule by his peers. His father was a surgeon's aide and the town drunk. His mother had come from a family with some means, which her husband was busily consuming with his drinking. Charles was raised with few rules and was left to run around the countryside as a young boy.

Later, he was to become a serious student. After some success at a college in Rouen (where he was in the middle of his class), his parents enrolled him at a medical school. They had decided that he should become a physician. At the beginning, his efforts at studying were noteworthy, but he became less enthusiastic and eventually stopped attending classes altogether. Instead, he frequented cabarets, playing dominos, and becoming acquainted with amour. After failing his examination and admitting his lack of interest to his parents, he resignedly went back to school, prepared again for his examinations, and this time was able to pass them with fairly good grades.

His controlling mother then found a small-town practice and a wife (an older widow of some means) for him, and he began practicing the art and science of medicine in a rural setting. He acquired a mediocre reputation. After the death of his first wife, he met a young girl, Emma Rouault, while attending to the broken leg of her father. Emma was to become the second "Madame Bovary." It was Emma who was the subject of Madame Bovary.

Emma was an attractive young woman, impetuous, full of ideas from books about romance, passion, felicity. She became bored with her rural life as the wife of a physician, and she succumbed to the temptations around her, having affairs with several men. She wanted to be a good wife to 
her husband and wished to have passion in their relationship, but it was not to be. She was described as more literate, more sensitive, more refined than Dr. Bovary, and she eventually felt mainly disgust for him.

Dr. Charles Bovary went to great efforts to placate the demands of his wife. At one point, they moved to a larger town, Yonville, with the hope of having a better life. It is there that they meet Mr. Homais, the town pharmacist, who plays an important role in this novel. Homais is ambitious, opinionated, and practices medicine without a proper license. Bovary is his competition, and in many ways Homais undermines Bovary while pretending to be his friend.

\section{The hook}

Homais had read a positive report of a new method to cure club feet and went to Emma Bovary to tell her of this new technique. He claimed that it would put their ordinary town in high regard as word got out that they were offering this new operation. As he explained to Emma: "What are we risking? There would be an almost certain success, the patient would be helped, and the surgeon would quickly achieve fame. Why, for instance, wouldn't your husband want to take care of that poor Hippolyte?" (Hippolyte was a poor, mentally challenged man with a club foot who lived in the stable at the inn.) "He [Hippolyte] wouldn't fail to tell all the travelers about his cure." Then Homais lowered his voice, looked around, and said, "Who would stop me from sending a little note to the newspaper about this... and then an article circulates, and one talks about it, and the snow ball grows, and who knows, who knows?" [2].

\section{The operation}

Dr. Bovary was convinced by his wife and Homais to undertake this procedure. He sent for a book about club feet, and spent hours studying it. Homais did his part by trying to convince Hippolyte to undergo the operation, grossly underestimating the risks and exaggerating the benefits, including the possibility of appealing to women. He also promised that this procedure would be done at no cost to him. The chance of having free care convinced Hippolyte to consent. Town craftsmen constructed a box of wood, leather, cloth, and screws that weighed some eight pounds. The procedure involved cutting a tendon and then placing the leg in the box. Dr. Bovary was confused about which tendon to cut, having never done such a procedure. With great angst he proceeded to cut the Achilles tendon, apparently successfully, and then placed the leg in the box and strapped it in. For several days after this operation,
Dr. Bovary was the toast of the town and even found his wife adoring and excited about their future life, as word would spread about this new procedure. Homais composed an exaggerated account of the event for the local newspaper. Everything went according to plan until 5 days later, when the patient had a seizure, smashing his box against the wall, apparently in great pain. Bovary and Homais withdrew the box and found a spectacle affreux - a terribly swollen and misshapen limb. After allowing some of the edema to subside with the appliance removed, they resolved to reapply the box and to tighten it even more to accelerate the healing process. Three days later, as the patient could no longer manage the pain, the box was again removed, and they found that the lower leg was dead. Local wound care was tried, but gangrene had begun to move up the leg. A priest was called and eventually so was a surgeon from another town, who performed an above-the-knee amputation to save the patient. Dr. Bovary, who had hoped for a positive result for both patient and doctor, was suddenly the object of scorn, derision, and embarrassment.

This fictional account of Dr. Bovary may teach us some important lessons, even today.

\section{Discussion}

What can we learn from Dr. Bovary? Do some of us have his foibles and weaknesses? Are we suffering from Dr. Bovary syndrome?

We physicians of the twenty-first century like to believe that we could never be susceptible to the temptations presented to Dr. Bovary. Trained in the scientific method, well aware of the latest scientific trials, able to point out whether a medical report has merit, surrounded by institutional review boards and credentials committees (which somewhat protect us from ourselves), it is less likely in today's world that we could be found taking the bait as eagerly as did poor Bovary. However, are we not still susceptible to this disease? As Jean-Baptiste Alphonse Karr once said: "Plus ça change, plus c'est la meme chose." (The more things change, the more they stay the same [3].) The basic characteristics of humankind have not changed that much over the years; and even today, despite modern education and much more rigid rules about physician conduct, we are prone to fall into the same traps.

Here is a brief checklist about the Dr. Bovary syndrome (DBS) that we might apply to ourselves.

1. Have you allowed your name to be used as an author of an article that is favorable about a new product or device and that was sponsored and paid for by the drug or device company-but you did not write it? If so, you may have DBS. 
2. Have you a list of disclosures of your affiliations with drug or device companies that takes up more than a small page? If so, you may have DBS.

3. Have you ever prescribed a medicine or used a medical device on a patient with the promise of an expensive gift or an exotic trip? If so, you suffer from DBS.

4. Have you ever been tempted to strengthen a manuscript by adding dreamed up data? If so, you are prone to DBS.

5. Have you lost focus on your primary task to deliver excellent care to your patient and allowed secondary concerns (academic appointments, increasing income, spreading your esteem, enlarging your practice) to influence decisions about your patient that were not necessarily in the patient's best interests? If so, DBS is the diagnosis.

What is the antidote to this sickness? One might consider the writings of Maimonides. His oath teaches us how we should be as physicians, in case any of us has forgotten.

The eternal providence has appointed me to watch over the life and health of Thy creatures. May the love for my art actuate me at all time; may neither avarice nor miserliness, nor thirst for glory or for a great reputation engage my mind; for the enemies of truth and philanthropy could easily deceive me and make me forgetful of my lofty aim of doing good to Thy children." (emphasis added) [4]

Some years ago, an intriguing article in Current Surgery [5] explored the notion that we continue to be willing, as a profession, to adopt "state-of-the-art" devices and treatments for our patients that are later discredited and found to be useless. Surely today we are also making mistakes with our patients that will in future years be grist for the publication mill. The idea that we do not have all the answers should humble us and keep us dedicated to continuous retrospection and improvement. Also, we should resolve to practice our art free from the sorts of challenges that brought down Dr. Bovary.

\section{References}

1. http://en.wikipedia.org/wiki/Madame_Bovary. Accessed 27 July 2011

2. Flaubert G (1972) Madame Bovary, Second Part, Chapter XI. Gallimard, Paris (translations by one of the authors, DRW)

3. http://en.wikipedia.org/wiki/Jean-Baptiste_Alphonse_Karr. Accessed 27 July 2011

4. http://en.wikipedia.org/wiki/Oath_of_Maimonides. Accessed 27 July 2011

5. Rich NM, Rob CG (1996) Surgical history: the bizarre, unusual, and useless in military surgery. Curr Surg 53:296-301 